\author{
AMERICAN JOURNAL OF FOOD AND NUTRITION \\ Print: ISSN 2157-0167, Online: ISSN 2157-1317, doi:10.5251/ajfn.2012.2.2.47.50 \\ (c) 2012, ScienceHuß, http://www.scihub.org/AJFN
}

\title{
Furfural production from the epicrap of wild mango (irvingia species) fruits by acid catalyzed hydrolysis
}

\author{
D. Wankasi ${ }^{1}$ and E.B Naidoo ${ }^{2}$ \\ ${ }^{1}$ Department of Chemical Sciences, Faculty of Science, Niger Delta University, Wilberforce \\ Island, P.M.B 071, Yenagoa, Bayelsa State, Nigeria. \\ Email: wankasi@yahoo.com \\ ${ }^{2}$ Department of Chemistry, Faculty of Applied and Computer Sciences, Vaal University of \\ Technology, Private Bag x021, Vanderbijl Park- 1900 South Africa- Andries Potgieter \\ Boulevard \\ Email: bobby@vut.ac.za
}

\begin{abstract}
The epicarp of wild mango (irvingia species) fruits were hydrolyzed with $4.5 \mathrm{M}$ hydrochloric acid solution and distilled. The distillates were tested for furfural using volumetric, Uv/visible and IR spectroscopic methods in addition to other physicochemical parameters. The Uv/visible and IR scans and the other tests confirm the presence of furfural. The result also show good yield of furfural.
\end{abstract}

Keywords: Furfural, production, irvingia species, hydrolysis

\section{INTRODUCTION}

Agricultural wastes are abundant, renewable, natural and rich sources of feedstock for chemicals. These agricultural by-products are more evenly spread all over the world in both terrestrial and aquatic environments. They are readily available in large quantity for use everywhere.

The importance of furfural and its derivatives has increased due to its very wide applications and this has made it imperative for the search for cheap, renewable and always available feedstock for the production of furfural.

Some of the applications of furfural and its derivatives include industrial chemicals and resins, solvent in petroleum industry, medicine, pesticides, antiseptics,disinfectors, insecticides, rust removers, and bio-fuels (De-Jong and Marcotullio 2010)

The possibility of using agricultural by-products for the production of furfural has been recognized for many years and over the last 60 years a more considerable fund of information has been built up. These include the production of furfural from corncorbs, rice hulls, bagasse (Saad etal, 1978), palm fruit fibre (Odozi etal, 1985), Garbage (Win, 2005), raphia hookeri (Wankasi and Tarawou, 2011), pawpaw and pineapple peels (Wankasi, etal, 2011) and Banana and plantain peels (Wankasi and Yabefa, 2011).

The low yield of furfural from straw and other materials makes it desirable to extract the aqueous furfural distillate after acid hydrolysis by a solvent heavier than water such as chloroform. Sometimes the distillate is treated with enough sodium hydroxide so that the mixture is left just faintly acid, and the furfural separated (Adams and Voorhees 2011).

Furfural can be produced by acid catalyzed hydrolysis of agricultural by- products containing hemi-cellulose or pentosan

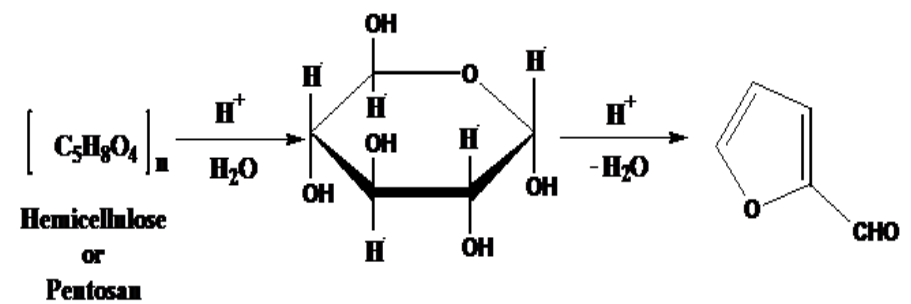

Pentosan is one of the important fibre component of non-starch polysaccharides called hemi-cellulose. Hemi-cellulose can be any of several heteropolymers present in almost all cell walls. 
There are two varieties of the wild mango, i.e I.Gabonensis with sweet pulp or skin and I.Wombolu with bitter pulp or skin. They all belong to the family of irvingiaceae (Harris 1996). Both irvingia species are found growing wild in the humid lowland Forests of tropical Africa in Angola, Cameroon, Central African Republic, Congo, Equitorial Guinea, Gabon, Zaire, Senegal and Nigeria (Harris 1996).

\section{MATERIALS AND METHODS}

Sample collection and preparation: Wild mango (irvingia species) fruits were obtained from Amassoma Town in Bayelsa State of Nigeria. The Epicarp were separated from the rest of the fruit. The epicarp were then oven dried at $60^{\circ} \mathrm{C}$ for 48 hours and ground to 500um mesh sizes.

Furfural production by Acid Hydrolysis: 30grams of the 500um mesh sizes of the epicarp of wild mango were weighed into a round bottom flask and refluxed with $500 \mathrm{ml}$ of $4.5 \mathrm{HCl}$ solution for one hour. The hydroxylate was cooled and stored in brown reagent bottles for further experimentation.

Distillation of hydroxylate: $300 \mathrm{ml}$ of the hydroxylate were put into a round-bottomed flask in distillation unit set up with a receiver containing chloroform. The hydroxylate was then distilled so that the distillate (furfural) passed directly into the layer of chloroform contained in the receiver. Distillation was continued until there was no increase in the chloroform layer.

Distillation of furfural/chloroform mixture (chloroform layer): $350 \mathrm{ml}$ of furfural/chloroform mixture were put into a round-bottomed flask in a distillation unit. The flask was heated with an electrothermal heating mantle. The chloroform was recovered at $60^{\circ} \mathrm{C}$ while the furfural remained in the flask.

Density of distillate: The empty density bottle was weighed and recorded. The density bottle was then filled with the distillate and the weight recorded. The difference in weight was taken and the density computed.

Boiling point determination: $70 \mathrm{ml}$ of distillate was measured into a clean $100 \mathrm{ml}$ beaker and a thermometer with a capillary tube tied together was inserted. The beaker with its content were then heated using a hot plate until the first bubble was observed. The temperature at this point was read and recorded.
pH of distillate: The pH meter was standardized with buffer solutions and then $25 \mathrm{ml}$ of each sample distillate was measured into a beaker. The $\mathrm{pH}$ values were read and recorded when the meter readings were stable.

Furfural estimation in distillate: $25 \mathrm{ml}$ of distillate was measured into a conical flask and $20 \mathrm{ml}$ of $0.05 \mathrm{M}$ potassium bromate/bromide $\left(\mathrm{KBrO}_{3} / \mathrm{KBr}\right)$ solution added and allowed to stand for five minutes. $10 \mathrm{ml}$ of $5 \%(0.05 \mathrm{M})$ potassium iodide $(\mathrm{kl})$ was then added and the liberated iodine titrated with a standard $0.1 \mathrm{M}$ sodium thiosulphate $\left(\mathrm{Na}_{2} \mathrm{SO}_{2} .5 \mathrm{H}_{2} \mathrm{O}\right)$ solution. Then the titre values (volumes of the $\mathrm{NaS}_{2} \mathrm{O}_{2} .5 \mathrm{H}_{2} \mathrm{O}$ ) were recorded. A blank experiment was conducted under the same conditions.

UV/Visible spectrophotometric scanning of distillates: A Jenway 6505 single beam scanning spectrophotometer was used to scan the distillates. The equipment was set to scan from $200-700 \mathrm{~nm}$ at a scan speed of $5 \mathrm{~mm}$ per minute.

IR Spectroscopic scanning of distillates: A drop of neat sample was placed between two polished flat sodium chloride plates (cells) which were squeezed together and mounted in the FTIR SPECTROPHOTOMETER (Model: Spectrum onePerkin Elma) and scanned.

\section{RESULTS AND DISCUSSION}

Table 1 gives the density of the distillate as $1.17 \mathrm{~g} / \mathrm{ml}$ for the irvingia fruit epicarps. This value is within the $1.16 \mathrm{~g} / \mathrm{ml}$ for furfural. This shows that the distillate was furfural.

Table1; physicochemical properties and percent yield of distillate

\section{TEST EPICARPS}

$\mathrm{pH}$

Density $(\mathrm{g} / \mathrm{ml})$

Colour

\%yield
Boiling point $\left.{ }^{(0} \mathrm{C}\right)$

\section{IRVINGIA FRUIT}

5.82

160

1.17

light brown

33.67
The boiling point as indicated in Table 1 is $160^{\circ} \mathrm{C}$. This value is within the $161.7^{\circ} \mathrm{C}$ for furfural and further confirms the conversion of the irvingia fruit epicarps to furfural. 
The $\mathrm{pH}$ value of 5.82 for the distillate is acidic. Table 1 also gives a fairly high percent yield of the furfural to be 33.67.

The carbonyl groups of saturated aldelydes and ketones give a weak absorption band in the ultraviolet region between $270-300 \mathrm{~nm}$. This band is shifted to longer wavelengths $(300-350 \mathrm{~nm})$ when the carbonyl group is conjugated with a double bond (Solomon, 1978).

As the degree of conjugation increases, the absorption will shift to longer wavelength. Generally, each additional double bond increases or gives rise to longer wavelength. Each additional conjugated double bond increases the wavelength of absorption band for about 300nm (Kamalu and Ogbome 2008).

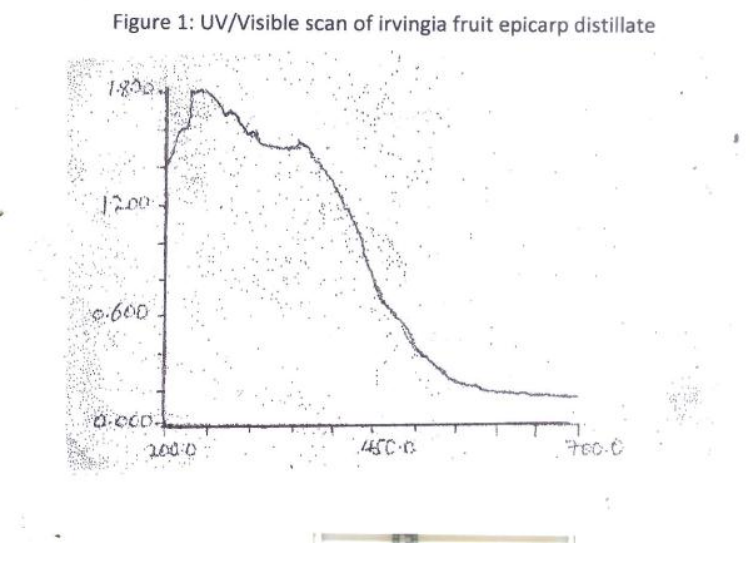

Examination of the resulting spectra as shown in figure 1 revealed broad absorption band in the region between $350-500 \mathrm{~nm}$ for the irvingia fruit epicarp distillate. This significant absorption band indicate the presence of conjugated unsaturated bonds. This also further confirms the presence of furfural as the broad band may be due to the conjugation in the furfural.

Carbonyl groups of aldehydes and ketones give rise to very strong $\mathrm{C}=0$ stretching bands in the 1665$1780 \mathrm{~cm}^{-1}$ region of the infraned spectrum. The exact location of the peak depends on the structure of the aldehyde or ketone. For example $\mathrm{RCHO}$ (1729$\left.1740 \mathrm{~cm}^{-1}\right) \mathrm{Ar}-\mathrm{CHO}\left(1695-1715 \mathrm{~cm}^{-1}\right), \quad-\mathrm{C}=\mathrm{C}-\mathrm{CHO}$ $\left(1680-1690 \mathrm{~cm}^{-1}\right)$ the $\mathrm{CHO}$ group of aldehydes also gives two weak bands in the $2700-2775 \mathrm{~cm}^{-1}$ and $2820-2900 \mathrm{~cm}^{-1}$ regions of the infrared spectrum (Solomon, 1978).

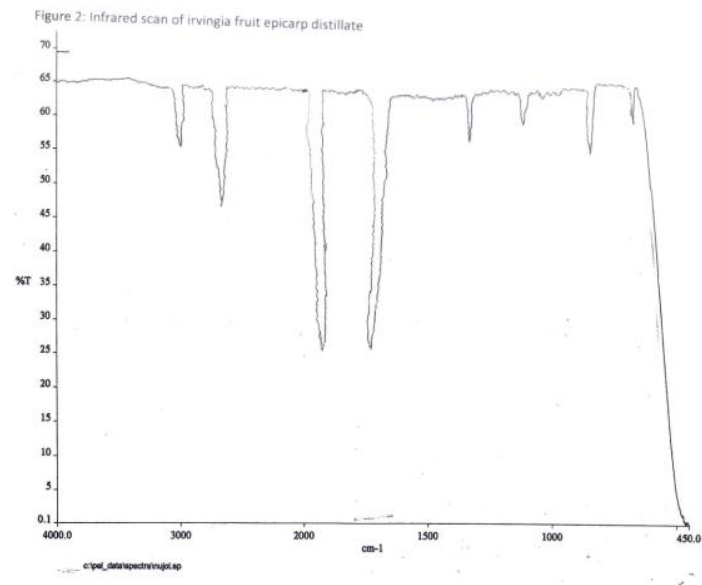

Figure 2 is the infrared spectrum of irvingia fruit epicarp distillate. The spectrum shows sharp peaks between $1640-1710 \mathrm{~cm}^{-1}$ for the distillate which indicate the presence of aldelyde. This further confirms the production of furfural from the epicarp of irvingia fruit by the acid catalyzed hydrolysis.

\section{CONCLUSION}

This study revealed a good yield of the furfural from the epicarp of irvingia fruits, which have been confirmed by the various tests including the Uv/visible and infrared spectrophotometric scans. Based on these findings, epicarps of irvingia fruits are good sources of renewable raw materials for the production of furfural. Furfural is a good source of chemicals and bio-fuels in the future bio-based economy.

\section{REFERENCES}

Adams $\mathrm{R}$ and Voorhees-checked by Clarke H. T. and Taylor E,R (2011); Organic synthesis, coll. Vol 1 pp.49 and 280 (copyright).

De- Jong W and Marcotullio G. (2010); Overview of Biorefineries based on co- production of furfural, Existing Concepts and Novel Developments. International Journal of Chemical Reactor Engineering, Vol 8, Article A69.

Harris D.J (1996). A Revision of the Irvingiacea in Africa. Bulletin du Jurdin. Batanique National de Belgique. 65 (1-2); 55-64

Kamalu O.I.C and Ogbome P. (2008); Extraction and Characterisation of Tiger Nut Oil J. chem. Soc. Nigeria, vol. 33, No 1, pp 79-87. 
Odozi T.O, Akaranta O. Ogban I. U. (1985). Development of Wood Varnishes from Palm Fruit Fibre Hydroxylate (Eliesis Gelineesis) and Red Onion skin (Allium cepa) Tannin Extract. JOCCA: 94-97

Saad S.M; Naser A.M; EL-Zi M, Abel-Moged (1978); 2Furfuraldehyde (furfural) from Local By-products and its Utilization in the Field of Surface Coatings. JOCCA 61: $41-48$

Solomon T.W.G. (1978). Organic Chemistry. John Whiley and Sons-New York. Chichelar Barisbane. Toronto.

Win T.D (2005); Furfural from Garbage. AUJT. 8(4); 185190
Wankasi D and Yabafa J. A (2011), Furfral Production from the Peels of Ripe Banana (musa sapientum L) by Acid catalyzed Hydrolysis. Electronic Journal of Environmental Agricultural and Food Chemistry (EJEAChe) 10(5) 2011 (2199-2205)

Wankasi, D and Tarawou T (2011). Furfural Production from Epicarp and Mesocarp of Raphia Hookeri Fruit by Acid catalyzed Hydrolysis. International Journal of Chemistry Vol. 21 No 2, 141-145

Wankasi D; Tarawou J.T and Yabefa A.J (2011). Furfural production from the peels of Ripe pawpaw (carica papaya) and pineapple (ananas comosus) fruits by Acid catalyzed Hydrolysis. American Journal of Food and Nutrition. 1(3): 136-140. 